\title{
Anti-inflammatory and Antioxidant Effects of Pluchea Indica Leaf Extract in TNF- $\alpha$-Induced Human Endothelial Cells
}

\author{
Klaokwan SRISOOK ${ }^{1,2, *}$, Suthasinee JINDA ${ }^{1}$ and Ekaruth SRISOOK ${ }^{2,3}$ \\ ${ }^{1}$ Department of Biochemistry and Research Unit of Natural Bioactive Compounds for Healthcare \\ Products Development, Faculty of Science, Burapha University, Chonburi 20131, Thailand \\ ${ }^{2}$ Center of Excellence for Innovation in Chemistry, Faculty of Science, Burapha University, \\ Chonburi 20131, Thailand \\ ${ }^{3}$ Department of Chemistry and Research Unit of Natural Bioactive Compounds for Healthcare Products \\ Development, Faculty of Science, Burapha University, Chonburi 20131, Thailand
}

('Corresponding author's e-mail: klaokwan@buu.ac.th, klaokwan@go.buu.ac.th)

Received: 18 May 2020, Revised: 22 February 2021, Accepted: 20 March 2021

\begin{abstract}
Pluchea Indica is a shrub plant found in mangrove forests. The leaves are consumed as food and herbal tea and exhibit various biological effects, such as antioxidant and anti-inflammatory activities, in macrophages and animal models. However, the inhibitory activity of $P$. Indica leaf extract on vascular inflammation remains unknown. Therefore, this study investigated the effect of an ethanol extract from $P$. Indica herbal tea leaves (PIE) on tumor necrosis factor- $\alpha$ (TNF- $\alpha$ )-induced human vascular endothelial EA.hy926 cells. The cytotoxic effect of PIE was determined by thiazolyl blue tetrazolium bromide assays. PIE at concentrations of $12.5-50 \mu \mathrm{g} / \mathrm{mL}$ did not show significant cytotoxicity, whereas PIE at concentrations $\geq 100 \mu \mathrm{g} / \mathrm{mL}$ decreased cell viability. PIE inhibited the production of reactive oxygen species (ROS) in TNF- $\alpha$-stimulated endothelial cells. To evaluate the PIE's anti-vascular inflammatory activity, the protein expression of cell adhesion molecules, including intercellular adhesion molecule-1 (ICAM-1) and vascular cell adhesion molecule-1 (VCAM-1), was determined by western blot. PIE significantly decreased TNF- $\alpha$-induced ICAM-1 and VCAM-1 expression in a concentration-dependent manner. Furthermore, PIE upregulated heme oxygenase-1 (HO-1) in a concentration- and time-dependent manner. Inhibiting the activity of HO-1 by tin protoporphyrin IX significantly blocked the suppressive effect of PIE on ICAM-1 but not VCAM-1 expression. Therefore, PIE exerts anti-inflammatory activity on vascular endothelial cells, at least in part, by suppressing ROS production and the induction of HO- 1 . The obtained data suggest that PIE is a promising substance for developing therapeutic agents or as an ingredient of functional food.
\end{abstract}

Keywords: Endothelium, Intercellular adhesion molecule, Pluchea Indica, Reactive oxygen species, Vascular cell adhesion molecule

\section{Introduction}

The World Health Organization reported that cardiovascular disease (CVD) was the number one cause of death globally in 2016, accounting for $31 \%$ of all deaths worldwide [1,2]. Atherosclerosis, the primary cause of CVD, is a condition in which blood vessels narrow from the accumulation of fatty plaques and foam cells on the blood vessel wall. The initial factors of atherosclerosis are inflammation, oxidative stress, and endothelial dysfunction [3-5]. After injurious factors stimulate endothelial cells lining blood vessels, they are triggered to produce pro-inflammatory cytokines and cell adhesion molecules, such as intercellular adhesion molecule (ICAM-1) and vascular cell adhesion molecule 
http://wjst.wu.ac.th

(VCAM-1), thereby enhancing the migration of leukocytes, which express more pro-inflammatory cytokines, to the inflamed site [6]. In addition, endothelial cells also exhibit increased oxidative stress by synthesizing reactive oxygen species (ROS), leading to increased inflammation and atherosclerosis [3,7]. Thus, reducing the oxidative stress and inflammatory response of endothelial cells might prevent atherosclerotic plaque progression and the development of CVDs.

Pluchea Indica Less. (Asteraceae) is a medicinal plant used for treating fever, dysentery, ulcers, rheumatism, soothe sores, and hemorrhoids [8-11]. The plant's leaves are consumed as food, both in the form of culinary vegetables and herbal tea [8]. P. Indica leaves have been studied to obtain the scientific data for their potential use as therapeutic agents. They possess various biological activities, such as antioxidant, anti-obesity, anti-diabetic, anti-glucosidase, anti-acetylcholinesterase, and anti-inflammatory activities [10-15]. In our previous report, we demonstrated that the hot water extract from P.Indica herbal tea leaves exhibited in vitro antioxidant activity and an inhibitory effect on the production of inflammatory mediators, including nitric oxide $(\mathrm{NO})$ and prostaglandin $\mathrm{E}_{2}\left(\mathrm{PGE}_{2}\right)$, in RAW 264.7 macrophages [12]. In addition, Buapool et al. [13] found that $P$. Indica leaf extract inhibited the production of $\mathrm{NO}$ and $\mathrm{PGE}_{2}$ in lipopolysaccharide (LPS)-induced macrophages by reducing NF- $\kappa \mathrm{B}$ activation. It was also shown to have anti-inflammatory effects in acute inflammation animal models by the suppression of ethyl phenylpropiolate-induced ear edema and carrageenan-induced paw edema in rats. However, the inhibitory effects of $P$. Indica leaf extract on vascular inflammation and ROS production in endothelial cells have not been described. Hence, in this study, we investigated the anti-inflammatory and antioxidant effects of an ethanol extract from $P$. Indica on human endothelial cells induced by TNF- $\alpha$. Our obtained data demonstrated the efficacy of $P$. Indica leaves and suggested the usefulness as therapeutic agents or functional food components.

\section{Materials and methods}

\section{Chemicals and reagents}

Dulbecco's modified Eagle's medium (DMEM), fetal bovine serum (FBS), penicillin-streptomycin solution, and $0.25 \%$ trypsin-EDTA were purchased from Invitrogen/Gibco (Grans Island, NY, USA). TNF- $\alpha$, thiazolyl blue tetrazolium bromide (MTT), and 2',7'dichlorodihydrofluorescein diacetate $\left(\mathrm{H}_{2} \mathrm{DCFDA}\right)$ were purchased from Sigma Chemical (St.Louis, MO, USA). Tin protoporphyrin IX (SnPP) was purchased from Cayman Chemical (Ann Arbor, MI, USA). Primary antibodies for CD54/ICAM-1, VCAM-1, HO-1, and glycerol-3-phosphate dehydrogenase (GAPDH) and goat anti-rabbit IgG horseradish peroxidase (HRP)-conjugated secondary antibodies were purchased from Cell Signaling Technology (Danvers, MA, USA). Protease inhibitor cocktail tablets, CL-XPosre film, and the Super Signal West Pico Chemiluminescent substrate were obtained from Thermo Scientific (Waltham, MA, USA). Tin protoporphyrin IX (SnPP) was from Cayman Chemical (Ann Arbor, MI, USA).

\section{Preparation of the ethanol extract from $P$. indica leaves}

The commercial $P$. Indica herbal tea product (dried leaves) was obtained from a biodiversity-based community enterprise in Bor sub-district, Khlung district, Chanthaburi province, Thailand. P. Indica herbal tea leaves were ground into powder, wrapped in cheesecloth, and soaked in a $95 \%$ ethanol solvent at a 1:10 ratio of plant powder to solvent for 5 days with occasional shaking. After that, the extract was filtered with Whatman paper no. 1. The plant powder was then re-extracted with ethanol 2 more times. The filtrates were pooled, and the extraction solvent was evaporated by a rotary vacuum evaporator to yield $P$. Indica leaf ethanol extract (PIE). The percentage yield of plant extract was $4.58 \%(\mathrm{w} / \mathrm{w})$.

\section{Culture of human endothelial cells}

The human vascular endothelial cell line EA.hy926 was obtained from ATCC and cultured in DMEM supplemented with $10 \%$ (v/v) FBS, penicillin $(100 \mathrm{U} / \mathrm{mL})$, and streptomycin $(100 \mu \mathrm{g} / \mathrm{mL})$. Cells were incubated at $37{ }^{\circ} \mathrm{C}$ in a humidified $5 \% \mathrm{CO}_{2}$ atmosphere and sub-cultured at $80-90 \%$ confluency by trypsinization. Dimethyl sulfoxide (DMSO) was used as vehicle control. 


\section{MTT cell viability assay}

Cells were seeded into a 24 -well culture plate at a density of $5 \times 10^{4}$ cells/well in $0.5 \mathrm{~mL}$ of medium. After attachment for $24 \mathrm{~h}$, cells were incubated in DMEM containing PIE at concentrations of 12.5$400 \mu \mathrm{g} / \mathrm{mL}$ at $37{ }^{\circ} \mathrm{C}$ for $24 \mathrm{~h}$. Then, cells were washed in phosphate-buffered saline (PBS), and $500 \mu \mathrm{L}$ of fresh culture media with MTT $(0.1 \mathrm{mg} / \mathrm{mL})$ was added into each well and further incubated for $3 \mathrm{~h}$ before aspiration of the cell culture medium. DMSO $(500 \mu \mathrm{L})$ was added to dissolve MTT-formazan crystals. The absorbance of the formazan solution was measured at $550 \mathrm{~nm}$. The percentage of cell viability was expressed as (absorbance of treated wells/absorbance of control wells) $\times 100$, as described by Srisook et al. $[16]$.

\section{Detection of ROS levels using an $\mathrm{H}_{2}$ DCFDA probe}

EA.hy926 cells were seeded into 6 -well culture plates at a density of $3 \times 10^{5}$ cells/well. Cells were incubated in serum-free DMEM at $37^{\circ} \mathrm{C}$ for $6 \mathrm{~h}$ and then treated with PIE $(12.5-50 \mu \mathrm{g} / \mathrm{mL}) \mathrm{for} 1 \mathrm{~h}$ before exposure to TNF- $\alpha$ at a concentration of $10 \mathrm{ng} / \mathrm{mL}$ for $2 \mathrm{~h}$. The cells were rinsed in a warm PBS buffer and incubated with DMEM containing $\mathrm{H}_{2}$ DCFDA $(50 \mu \mathrm{M})$ at $37^{\circ} \mathrm{C}$ for $30 \mathrm{~min}$ in the dark. After removing the growth medium, ice-cold PBS buffer was added to each well, and the cells were scraped in PBS buffer on ice. The fluorescence of 2',7'-dichlorofluorescein (DCF) was measured at an excitation wavelength of $485 \mathrm{~nm}$ and emission wavelength at $521 \mathrm{~nm}$ using a fluorescence spectrophotometer (Cary Eclipse, Agilent, USA.).

\section{Protein extraction for western blot analysis}

EA.hy926 cells $\left(3 \times 10^{5}\right.$ cells $/ 60-\mathrm{mm}$ plate) were plated and treated with PIE at a concentration of $12.5-50 \mu \mathrm{g} / \mathrm{mL}$ for $1 \mathrm{~h}$ before incubation with TNF- $\alpha(10 \mathrm{ng} / \mathrm{mL})$ for $6 \mathrm{~h}$. After that, cells were washed twice with ice-cold PBS buffer before being scraped in RIPA protein lysis buffer [150 mM Tris- $\mathrm{HCl}$, $150 \mathrm{mM} \mathrm{NaCl}$, 5. mM EGTA, $0.1 \%$ SDS, $1 \%$ sodium deoxycholate, $1 \%$ nonidet P-40, $1 \mathrm{mM}$ DTT, and $1 \mathrm{X}$ protease inhibitors]. Then, cell lysates were transferred to a microtube and centrifuged at $13,700 \mathrm{~g}$ for $10 \mathrm{~min}$ at $4{ }^{\circ} \mathrm{C}$. The protein content in supernatants was analyzed by the Bradford assay and stored at -80 ${ }^{\circ} \mathrm{C}$ before being analyzed by western blot.

Proteins were separated by $10 \%$ SDS-polyacrylamide gel electrophoresis and transferred to a polyvinylidene difluoride (PVDF) membrane. The membrane was immersed with a blocking solution [10 mM Tris- $\mathrm{HCl}(\mathrm{pH} 7.5), 150 \mathrm{mM} \mathrm{NaCl}, 0.1 \%(\mathrm{v} / \mathrm{v})$ Tween 20, and $5 \%(\mathrm{w} / \mathrm{v})$ skim milk] at room temperature for $1 \mathrm{~h}$ and then incubated with primary antibodies for VCAM-1, ICAM-1, HO-1, or GAPDH diluted 1:1,000 in 1X TBS buffer containing $5 \%(\mathrm{w} / \mathrm{v})$ BSA and $0.1 \%(\mathrm{v} / \mathrm{v})$ Tween 20 overnight with shaking at $4{ }^{\circ} \mathrm{C}$. Then, the PVDF membrane was washed with TBS-T buffer at room temperature 3 times for $5 \mathrm{~min}$ each and incubated with the secondary antibody (HRP-linked anti-rabbit $\mathrm{IgG}$ ) diluted 1:5,000 in blocking solution for $1 \mathrm{~h}$ at room temperature. After incubation, the membrane was rinsed 3 times with TBS-T buffer and immersed in an ECL substrate solution. The specific protein bands on membranes were detected on CL-XPosre film. The intensities of each band signal were determined by densitometry using Image Studio Lite version 5.2 Free Western Blot Analysis Software. Image densities of specific bands for VCAM-1, ICAM-1, and HO-1 were normalized with the density of the GAPDH band.

\section{Statistical analysis}

All experiments were replicated at least 3 times. Data are presented as the mean $\pm \mathrm{SD}$. One-way analysis of variance and Tukey's test for multiple comparisons were used to determine statistical significance by Minitab version 18 for Windows. A $p$-value of $<0.05$ was considered statistically significant. 
http://wjst.wu.ac.th

\section{Results and discussion}

Effect of $P$. Indica leaf ethanol extract (PIE) on the viability of human endothelial cells

The cell viability of human vascular endothelial EA.hy926 cells exposed to PIE at various concentrations ( 0 to $400 \mu \mathrm{g} / \mathrm{mL}$ ) for $24 \mathrm{~h}$ was determined by the MTT assay. It was found that PIE at concentrations of $12.5-50 \mu \mathrm{g} / \mathrm{mL}$ did not show significant toxicity compared with control cells, whereas PIE at concentrations of $100-400 \mu \mathrm{g} / \mathrm{mL}$ significantly decreased cell viability. The percentage of viable cells after exposure to PIE at concentrations of 100,200 , and $400 \mu \mathrm{g} / \mathrm{mL}$ decreased to $54.9 \pm 1.8 \%, 27.5$ $\pm 2.3 \%$, and $26.4 \pm 2.5 \%$, respectively, compared with the control cells (Figure 1). Therefore, the concentration of PIE used in subsequent experiments was not more than $50 \mu \mathrm{g} / \mathrm{mL}$ to avoid the toxic effects of the extract.

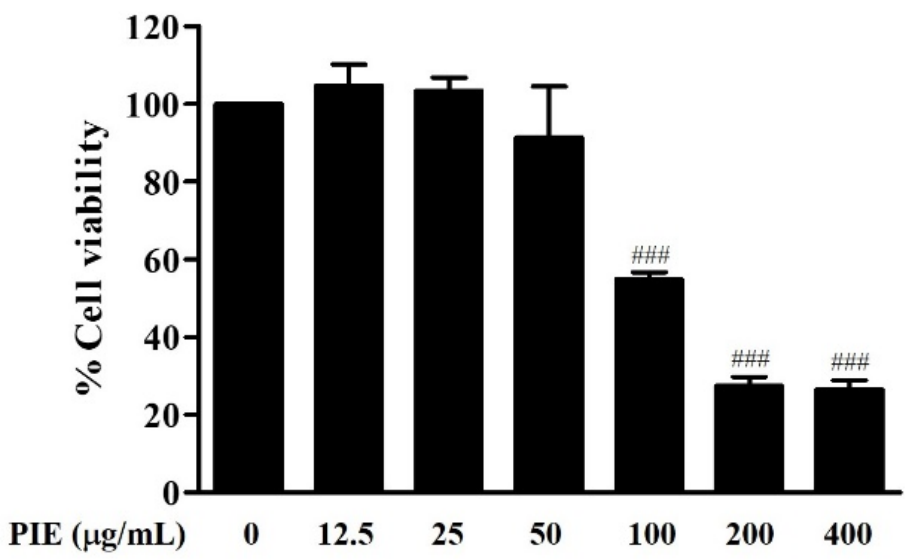

Figure 1 Cell viability of human endothelial EA.hy926 cells exposed to PIE (12.5 - $400 \mu \mathrm{g} / \mathrm{mL})$ for $24 \mathrm{~h}$ was determined by the MTT method. ${ }^{\# \#} p<0.001$ compared with the unstimulated control cells.

\section{Antioxidant effect of PIE on TNF- $\alpha$-induced human endothelial cells}

ROS are associated with the pathogenesis of atherosclerosis in several steps, including the activation of inflammation, endothelial dysfunction, recruitment of leukocytex, and proliferation of smooth muscle cells $[3,17,18]$. Vascular endothelial cells in the inflammatory site are stimulated by inflammatory triggers, such as TNF- $\alpha$, to increase the activity of NADPH oxidase, which produces a large number of superoxide radicals that are converted into other ROS, leading to oxidative stress [3,7]. Therefore, we determined the effect of PIE extract on intracellular ROS production in human endothelial cells. Cell-based antioxidant activity was assessed using an $\mathrm{H}_{2}$ DCFDA probe, which is oxidized by intracellular ROS to fluorescent DCF [19]. From the results shown in Figure 2, the intracellular ROS level following TNF- $\alpha$ treatment was statistically significantly increased compared with that in the unstimulated control cells. PIE at the non-toxic doses of $12.5-50 \mu \mathrm{g} / \mathrm{mL}$ significantly reduced TNF- $\alpha$ stimulated ROS production in a concentration-dependent manner compared with cells induced by TNF- $\alpha$ alone. In addition to showing in vitro antioxidant activity of the $P$. Indica leaf extract [12], this study also demonstrated the antioxidant activity of the plant leaves in TNF- $\alpha$-induced endothelial cells. This result suggests that the bioactive compounds in PIE exhibited ROS scavenging effects in endothelial cells that might protect against the development of atherosclerosis. 
http://wjst.wu.ac.th

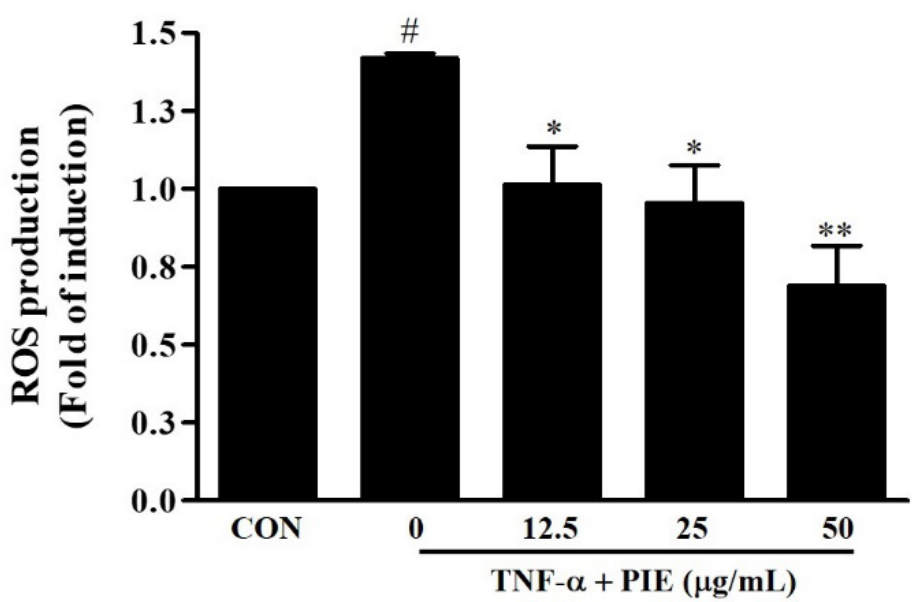

Figure 2 Inhibitory effect of PIE on intracellular ROS levels. Endothelial cells were exposed to PIE at the indicated concentrations for $1 \mathrm{~h}$ and induced by TNF- $\alpha(10 \mathrm{ng} / \mathrm{mL})$ for $2 \mathrm{~h}$. Intracellular ROS levels were detected using the $\mathrm{H}_{2}$ DCFDA probe. ${ }^{*} p<0.05$ compared with unstimulated control cells. ${ }^{*} p<0.05$ and ** $p<0.01$ compared with cells induced by TNF- $\alpha$ alone.

\section{Anti-inflammatory effect of PIE on TNF- $\alpha$-induced human endothelial cells}

In addition to endothelial dysfunction and oxidative stress, endothelial inflammation is one of the main causes of atherosclerosis, which can lead to the development of CVDs [3-5]. Inflammatory responses involve vasodilation, increased permeability of blood vessels, leakage of protein and fluid out of blood vessels, and leukocyte extravasation to inflamed areas. The migration of leukocytes begins with the leukocytes binding to cell adhesion molecules of blood vessels and moving through the gaps between the cells lining the blood vessels to the outside of the blood vessels. This process is controlled by molecules expressed on the surface of vascular endothelial cells, including VCAM-1, ICAM-1, and Eselectin. Once leukocytes move to the site of inflammation, they are activated to release inflammatory cytokines, such as TNF- $\alpha$ and interleukin (IL)-1 $\beta$, which stimulate the synthesis of adhesion molecules on endothelial cells to promote the infiltration of leukocytes $[6,18]$. The substances that can inhibit the expression of cell adhesion molecules will decrease the adhesion of leukocytes to vascular endothelial cells leading to less movement outside of blood vessels and consequently reduced vascular inflammation. Thus, the anti-vascular inflammatory effect of PIE on human endothelial EA.hy926 cells was examined using western blot analysis. Here, we demonstrated that cells exposed to TNF- $\alpha$ alone showed substantially increased levels of ICAM-1 and VCAM-1 proteins compared with unstimulated control cells. PIE at concentrations of $25-50 \mu \mathrm{g} / \mathrm{mL}$ significantly reduced ICAM-1 and VCAM-1 protein expression (Figure 3). This result is consistent with our previous studies showing the anti-inflammatory effect of $P$. Indica leaf extract in LPS-stimulated RAW 264.7 macrophages and ethyl phenylpropiolateand carrageenan-induced acute inflammation rat models $[12,13]$. The data obtained from the present study support our previous study since a crucial step in the initiation of inflammation is leukocyte adhesion and emigration through the arterial intima of blood vessels to the inflamed site [20]. 


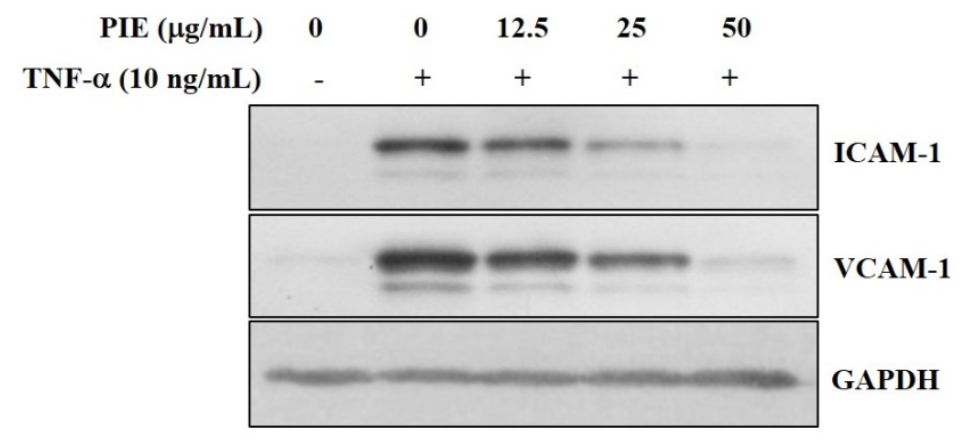

(A)

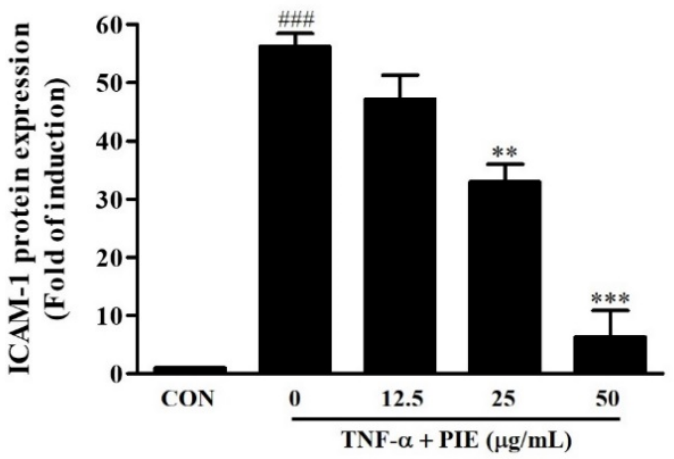

(B)

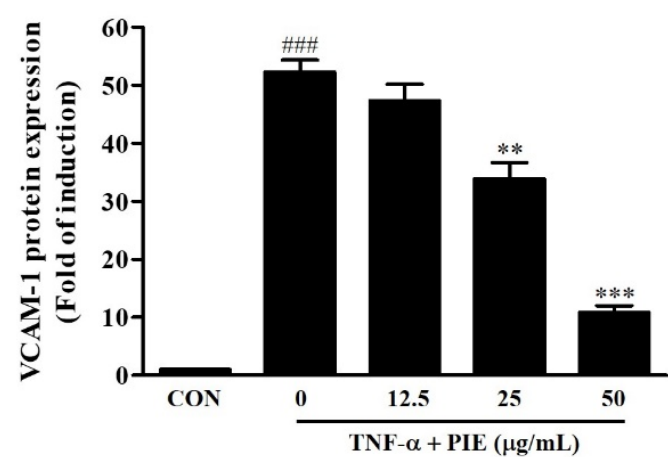

(C)

Figure 3 Inhibitory effect of PIE on the protein expression of ICAM-1 and VCAM-1. Human endothelial EA.hy926 cells were exposed to PIE $(12.5-50 \mu \mathrm{g} / \mathrm{mL})$ for $1 \mathrm{~h}$ and induced by TNF- $\alpha(10 \mathrm{ng} / \mathrm{mL})$ for $6 \mathrm{~h}$. The protein levels of ICAM-1 and VCAM-1 were examined by western blot analysis (A). The graph shows the mean \pm SD from densitometric analyses of ICAM-1 (B) or VCAM-1 (C) proteins normalized to GAPDH. ${ }^{\# \#} p<0.001$ compared with the unstimulated control cells; ${ }^{* *} p<0.01$ and ${ }^{* * *} p<0.001$ compared with cells induced by TNF- $\alpha$ alone.

\footnotetext{
Involvement of HO-1 activation in the anti-inflammatory effect of PIE on human endothelial cells

$\mathrm{HO}$ is an enzyme that catalyzes the breakdown of heme into biliverdin, free iron, and carbon monoxide. Biliverdin is rapidly converted into bilirubin by biliverdin reductase. This enzyme has 3 isoforms, including $\mathrm{HO}-1, \mathrm{HO}-2$, and $\mathrm{HO}-3$ [21]. HO-1 is classified as an antioxidant defense enzyme because its products, such as biliverdin and bilirubin, act as antioxidants [21,22]. Furthermore, HO-1 causes the breakdown of the pro-oxidant molecule heme [23]. HO-1 is also an enzyme that relieves inflammation by its products $[24,25]$. Carbon monoxide reduces the levels of inflammatory cytokines, such as IL- 6 and TNF- $\alpha$, in a necrotizing enterocolitis rat model and trinitrobenzene sulfonic acid-induced colitis in mice $[26,27]$. Also, carbon monoxide has been reported to exert an anti-inflammatory effect by inhibiting NF- $\mathrm{KB}$ signaling via the reduction of $\mathrm{I} \kappa \mathrm{B}$ phosphorylation, preventing NF- $\mathrm{KB}$ from translocating to the nucleus $[28,29]$ and suppressing binding to the NF- $\mathrm{kB}$ site at the promoter of inflammation-related genes, including ICAM-1 and VCAM-1 [30,31].
} 
http://wjst.wu.ac.th
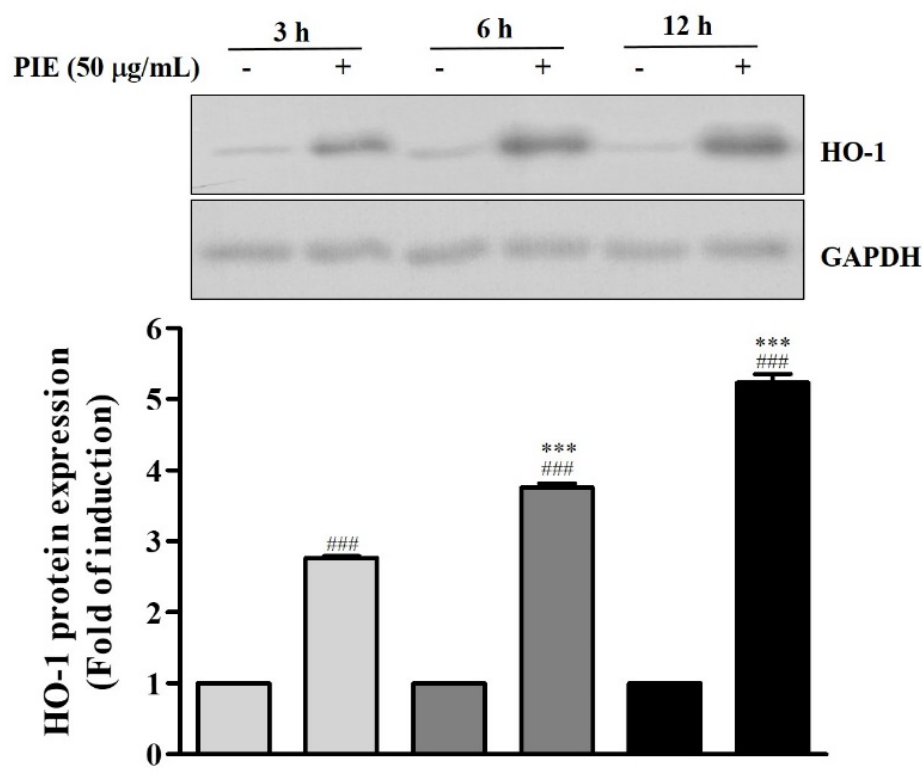

(A)
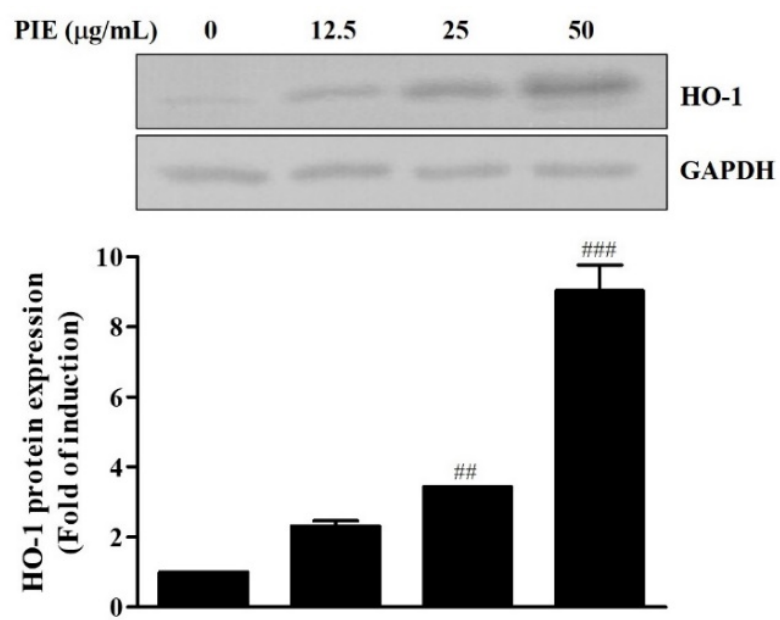

(B)

Figure 4 Stimulation of HO-1 protein expression by PIE. (A) Endothelial cells were exposed to PIE $(50 \mu \mathrm{g} / \mathrm{mL})$ for 3,6 , and $12 \mathrm{~h}$, and HO-1 protein content was measured by western blot analysis. The

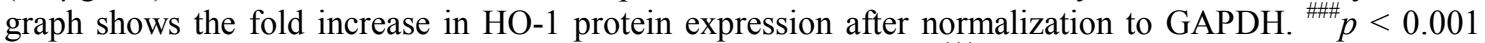
compared with the unstimulated control cells at each time point; ${ }^{* * *} p<0.001$ compared with cells that were stimulated by PIE at $3 \mathrm{~h}$. (B) Cells were treated with PIE at concentrations of $12.5-50 \mu \mathrm{g} / \mathrm{mL}$ for $12 \mathrm{~h}$. HO-1 protein levels were determined by western blotting analysis. The graph shows the fold increase in HO-1 protein expression after normalization to GAPDH. ${ }^{\# \#} p<0.01$ and ${ }^{\# \#} p<0.001$ compared with the unstimulated control cells. 
http://wjst.wu.ac.th

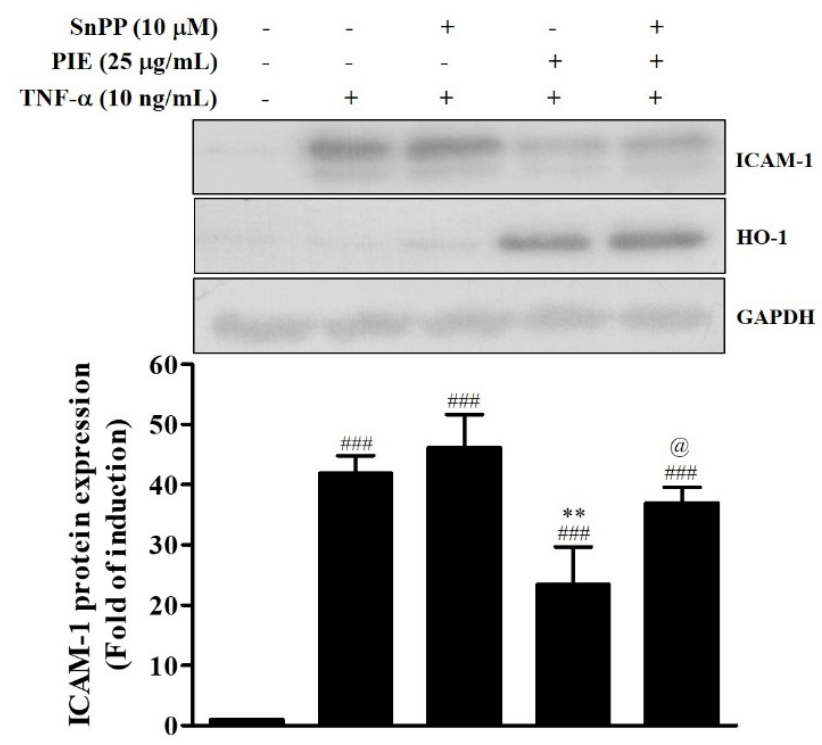

(A)

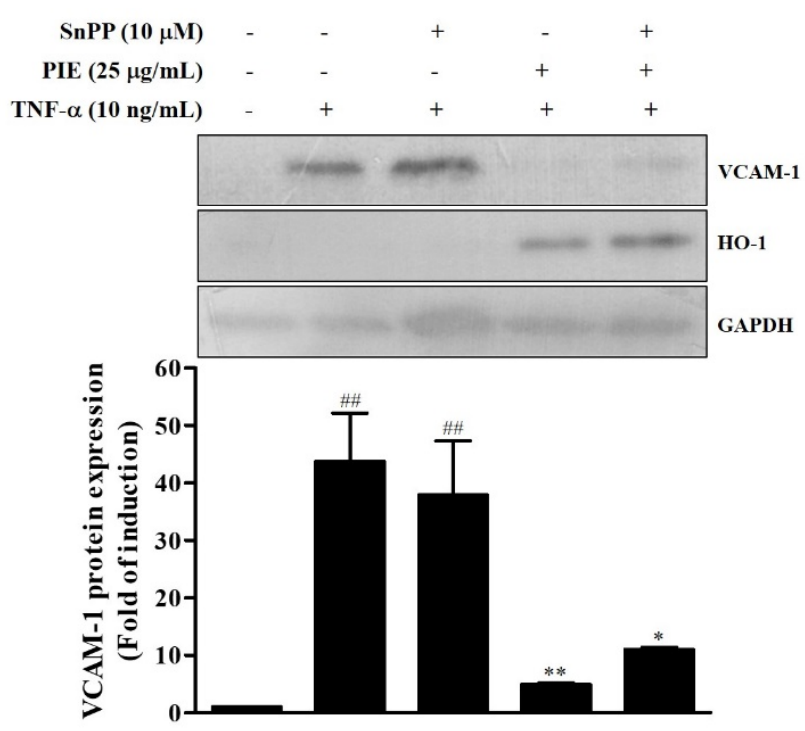

(B)

Figure 5 HO-1mediates the reduction in TNF- $\alpha$-induced ICAM-1 and VCAM-1 expression in human endothelial EA.hy926 cells induced by PIE. Endothelial cells were exposed to PIE $(25 \mu \mathrm{g} / \mathrm{mL})$ and SnPP $(10 \mu \mathrm{M})$ for $1 \mathrm{~h}$ and stimulated by TNF- $\alpha(10 \mathrm{ng} / \mathrm{mL})$ for $6 \mathrm{~h}$. The graph shows the fold increase in ICAM-1 (A) and VCAM-1 (B) levels after normalization to GAPDH. ${ }^{\#} p<0.01$ and ${ }^{\# \# \#} p<0.001$ compared with the unstimulated control cells, ${ }^{*} p<0.05$ and ${ }^{* *} p<0.01$ compared with TNF- $\alpha$ induced cells, ${ }^{@} \mathrm{p}<0.005$ compared with TNF- $\alpha$ plus PIE. 
http://wjst.wu.ac.th

It has been shown that the heme degradation products of HO-1-catalyzed reactions mediate antiinflammatory and antioxidant effects of a variety of plant extracts [32-36]. We hypothesized that the suppression of ICAM-1 and VCAM-1 expression in EA.hy926 cells induced by PIE may be the result of HO-1 activation. Thus, the effect of PIE on HO-1 expression was examined in the present study. HO-1 protein levels were determined in human vascular endothelial cells exposed to PIE at concentrations of $50 \mu \mathrm{g} / \mathrm{mL}$ for 3,6 , and $12 \mathrm{~h}$. PIE significantly induced the protein level of HO-1 compared with that of control cells at each time point (Figure 4A). The protein expression of HO-1 gradually increased with time, markedly increased after $3 \mathrm{~h}$ of exposure, and reached a maximum expression at $12 \mathrm{~h}$. Further studies examined the protein level of HO-1 in cells treated with PIE at a concentration of $12.5-50 \mu \mathrm{g} / \mathrm{mL}$ for $12 \mathrm{~h}$. HO-1 protein expression increased as the concentration of PIE increased (Figure 4B). These data indicate that PIE contains 1 or more plant compounds that are potent inducers of HO-1 expression. According to our results, PIE inhibited ICAM-1 and VCAM-1 expression. Therefore, we next investigated whether HO-1 activation is involved in the mechanism of action of PIE in TNF- $\alpha$-induced endothelial cells. As shown in Figure 5, PIE inhibited the expression of ICAM-1 and VCAM-1 on TNF$\alpha$-stimulated human endothelial cells, whereas SnPP, an inhibitor of HO-1 activity, reversed the inhibitory effect of PIE resulting in a statistically significant increase in ICAM-1 but not VCAM-1 protein expression compared with the cells exposed to TNF- $\alpha$ and PIE. In addition, the expression of HO-1 increased compared with unstimulated control cells. This might be explained by the products produced from enhanced HO-1 activity induced by PIE suppressing ROS production resulting in inhibition of NF$\kappa \mathrm{B}$ activity, which causes a reduction in ICAM-1 and VCAM-1 proteins. Inhibiting HO-1 activity by SnPP leads to less productivity and thus diminishes the inhibition of NF- $\kappa B$ activity resulting in increased ICAM-1 and VCAM-1 protein expression. Our findings in the present study might support the previous reports that HO-1 activation contributes to reduced atherosclerosis, at least in part, by modulating ICAM1 and VCAM-1 expression [21].

Previous studies showed that $P$. Indica leaf extract contained acetylenic thiophenes, caffeoylquinic acid derivatives, and flavonoids including apigenin, luteolin, and quercetin [13,14,37]. Notably, quercetin inhibited ICAM-1 expression in PMA- and TNF- $\alpha$-induced ECV304 human endothelial cells by inhibiting the JNK pathway [38]. Besides, chlorogenic acid and quercetin were found to reduce inflammation by inhibiting the expression of cell adhesion molecules in TNF- $\alpha$-induced human umbilical vein endothelial cells [39]. Wang et al. also showed that 5-caffeoylquinic-acid suppressed TNF- $\alpha$-induced ROS production in EA.hy926 cells [40]. However, the compounds responsible for the anti-vascular inflammatory activity of PIE require further study.

\section{Conclusions}

Based on the findings in this study, we conclude that PIE exhibits an anti-inflammatory effect on TNF- $\alpha$-induced endothelial cells by reducing the production of ROS and decreasing the expression of ICAM-1 and VCAM-1 proteins that is mediated partly through the upregulation of HO-1. The results indicate that PIE might improve vascular inflammation by inhibiting the cell adhesion molecules and oxidative stress. However, further investigations need to elucidate the exact mechanism by which PIE exerts its inhibitory effect on ICAM-1 and VCAM-1 expression and ROS production.

\section{Acknowledgment}

This work was financially supported by the Research Grant of Burapha University through National Research Council of Thailand (Grant no.52/2561) and for the Research Unit of Natural Bioactive Compounds for Healthcare Products; by Science Innovation Facility, Faculty of Science, Burapha University (SIF-IN-59030281); and by the Center of Excellence for Innovation in Chemistry (PERCHCIC), Commission on Higher Education, Ministry of Education, Thailand. 
http://wjst.wu.ac.th

\section{References}

[1] GA Mensah, GA Roth and V Fuster. The global burden of cardiovascular diseases and risk factors: 2020 and beyond. J. Am. Coll. Cardiol. 2019; 74, 2529-32.

[2] World Health Organization (WHO). Cardiovascular diseases (CVDs) Fact sheet. Available at: https://www.who.int/en/news-room/fact-sheets/detail/cardiovascular-diseases-(cvds), accessed April 2020.

[3] AJ Kattoor, NVK Pothineni, D Palagiri and JL Mehta. Oxidative stress in atherosclerosis. Curr. Atheroscler. Rep. 2017; 19, 42.

[4] S Steven, K Frenis, M Oelze, S Kalinovic, M Kuntic, MTB Jimenez, K Vujacic-Mirski, J Helmstädter, S Kröller-Schön, T Münzel and A Daiber. Vascular inflammation and oxidative stress: Major triggers for cardiovascular disease. Oxid. Med. Cell Longev. 2019; 2019, 7092151.

[5] A Daiber and S Chlopicki. Revisiting pharmacology of oxidative stress and endothelial dysfunction in cardiovascular disease: Evidence for redox-based therapies. Free Radic. Biol. Med. 2020; 157, 15-37.

[6] S Liu, Y Dong, T Wang, S Zhao, K Yang, X Chen and C Zheng. Vaspin inhibited proinflammatory cytokine induced activation of nuclear factor-kappa B and its downstream molecules in human endothelial EA.hy926 cells. Diabetes Res. Clin. Pract. 2014; 103, 482-8.

[7] J Wu, S Xia, B Kalionis, W Wan and T Sun. The role of oxidative stress and inflammation in cardiovascular aging. Biomed. Res. Int. 2014; 2014, 615312.

[8] Office of Mangrove Resources Conservation. Department of Marine and Coastal Resources, Ministry of Natural Resources and Environment. Plants in the mangrove forest of Thailand (in Thai). Printing House of the Agricultural Co-operative Federation of Thailand Limited, Nonthaburi, Thailand, 2009.

[9] T Sen, TK Ghosh and AK Chaudhuri. Studies on the mechanism of anti-inflammatory and antiulcer activity of Pluchea indica probable involvement of 5-lipooxygenase pathway. Life Sci. 1993; 52, 737-43.

[10] AR Noridayu, YF Hii, A Faridah, S Khozirah and N Lajis. Antioxidant and antiacetylcholinesterase activities of Pluchea indica Less. Int. Food Res. J. 2011; 18, 925-9.

[11] K Sirichaiwetchakoon, GM Lowe, K Thumanu and G Eumkeb. The effect of Pluchea indica (L.) Less. tea on adipogenesis in 3T3-L1 adipocytes and lipase activity. Evid. Based Complement Altern. Med. 2018; 2018, 4108787.

[12] K Srisook, D Buapool, R Boonbai, P Simmasut, Y Charoensuk and E Srisook. Antioxidant and antiinflammatory activities of hot water extract from Pluchea indica Less herbal tea. J. Med. Plant Res. $2012 ; 6,4077-81$.

[13] D Buapool, N Mongkol, J Chantimal, S Roytrakul, E Srisook and K Srisook. Molecular mechanism of anti-inflammatory activity of Pluchea indica leaves in macrophages RAW 264.7 and its action in animal models of inflammation. J. Ethnopharmacol. 2013; 146, 495-504.

[14] B Vongsak, S Kongkiatpaiboon, S Jaisamut and K Konsap. Comparison of active constituents, antioxidant capacity, and alpha-glucosidase inhibition in Pluchea indica leaf extracts at different maturity stages. Food Biosci. 2018; 25, 68-73.

[15] J Nopparat, A Nualla-Ong and A Phongdara. Ethanolic extracts of Pluchea indica (L.) leaf pretreatment attenuates cytokine-induced $\beta$-cell apoptosis in multiple low-dose streptozotocininduced diabetic mice. PLoS One 2019; 14, e0212133.

[16] K Srisook, E Srisook, W Nachaiyo, M Chan-In, J Thongbai, K Wongyoo, S Chawsuanthong, K Wannasri, S Intasuwan and K Watcharanawee. Bioassay-guided isolation and mechanistic action of anti-inflammatory agents from Clerodendrum inerme leaves. J. Ethnopharmacol. 2015; 165, 94102.

[17] WM Huang, YQ Liang, LJ Tang, Y Ding and XH Wang. Antioxidant and anti-inflammatory effects of Astragalus polysaccharide on EA.hy926 cells. Exp. Ther. Med. 2013; 6, 199-203.

[18] L Stoner, AA Lucero, BR Palmer, LM Jones, JM Young and J Faulkner. Inflammatory biomarkers for predicting cardiovascular disease. Clin. Biochem. 2013; 46, 1353-71. 
http://wjst.wu.ac.th

[19] KK Griendling, RM Touyz, JL Zweier, S Dikalov, W Chilian, YR Chen, DG Harrison, A Bhatnagar and American Heart Association Council on Basic Cardiovascular Sciences. Measurement of reactive oxygen species, reactive nitrogen species, and redox-dependent signaling in the cardiovascular system: A scientific statement from the American Heart Association. Circ. Res. 2016; 119, e39-e75.

[20] JS Hwa, L Mun, HJ Kim, HG Seo, JH Lee, JH Kwak, DU Lee and KC Chang. Genipin selectively inhibits TNF- $\alpha$-activated VCAM-1 but not ICAM-1 expression by upregulation of PPAR- $\gamma$ in human endothelial cells. Korean J. Physiol. Pharmacol. 2011; 15, 157-62.

[21] $\mathrm{Y}$ Kishimoto, $\mathrm{K}$ Kondo and $\mathrm{Y}$ Momiyama. The protective role of heme oxygenase-1 in atherosclerotic diseases. Int. J. Mol. Sci. 2019; 20, 3628.

[22] SK Chiang, SE Chen and LC Chang. A dual role of heme oxygenase-1 in cancer cells. Int. J. Mol. Sci. 2019; 20, 39.

[23] S Immenschuh, V Vijayan, S Janciauskiene and F Gueler. Heme as a target for therapeutic interventions. Front. Pharmacol. 2017; 8, 146.

[24] K Srisook, SS Han, HS Choi, MH Li, H Ueda, C Kim and YN Cha. CO from enhanced HO activity or from CORM-2 inhibits both O2- and NO production and downregulates HO-1 expression in LPS-stimulated macrophages. Biochem. Pharmacol. 2006; 71, 307-18.

[25] V Vijayana, FADTG Wagenerb and S Immenschuh. The macrophage heme-heme oxygenase-1 system and its role in inflammation. Biochem. Pharmacol. 2018; 153, 159-67.

[26] BS Zuckerbraun, LE Otterbein, P Boyle, R Jaffe, J Upperman, R Zamora and HR Ford. Carbon monoxide protects against the development of experimental necrotizing enterocolitis. Am. J. Physiol. Gastrointest. Liver Physiol. 2005; 289, G607-G613.

[27] W Fukuda, T Takagi, K Katada, K Mizushima, T Okayama, N Yoshida, K Kamada, K Uchiyama, T Ishikawa, O Handa, H Konishi, N Yagi, H Ichikawa, T Yoshikawa, G Cepinskas, Y Naito and Y Itoh. Anti-inflammatory effects of carbon monoxide-releasing molecule on trinitrobenzene sulfonic acid-induced colitis in mice. Dig. Dis. Sci. 2014; 59, 1142-51.

[28] JK Sarady, SL Otterbein, F Liu, LE Otterbein and AMK Choi. Carbon monoxide modulates endotoxin-induced production of granulocyte macrophage colony-stimulating factor in macrophages. Am. J. Respir. Cell Mol. Biol. 2002; 27, 739-45.

[29] P Sawle, R Foresti, BE Mann, TR Johnson, CJ Green and R Motterlini. Carbon monoxide-releasing molecules (CO-RMs) attenuate the inflammatory response elicited by lipopolysaccharide in RAW264.7 murine macrophages. Br. J. Pharmacol. 2005; 145, 800-10.

[30] C Chen, C Chou, Y Sun and W Huang. Tumor necrosis factor alpha-induced activation of downstream NF-kappaB site of the promoter mediates epithelial ICAM-1 expression and monocyte adhesion. Involvement of PKCalpha, tyrosine kinase, and IKK2, but not MAPKs, pathway. Cell Signal 2001; 13, 543-53.

[31] JK Min, YM Kim, SW Kim, MC Kwon, YY Kong, IK Hwang, MH Won, J Rho and YG Kwon. TNF-related activation-induced cytokine enhances leukocyte adhesiveness: Induction of ICAM-1 and VCAM-1 via TNF receptor-associated factor and protein kinase C-dependent NF- $\mathrm{KB}$ activation in endothelial cells. J. Immunol. 2005; 175, 531-40.

[32] K Srisook, M Palachot, N Mongkol, E Srisook and S Sarapusit. Anti-inflammatory effect of ethyl acetate extract from Cissus quadrangularis Linn may be involved with induction of heme oxygenase-1 and suppression of NF- $\mathrm{BB}$ activation. J. Ethnopharmacol. 2011; 133, 1008-14.

[33] ES Choi, YJ Lee, CS Seo, JJ Yoon, BH Han, MC Park, Kang DG Kang and HS Lee. Vascular protective role of Samul-Tang in HUVECs: Involvement of Nrf2/HO-1 and NO. Evid. Based Complement Altern. Med. 2016; 2016, 9580234.

[34] JJ Yoon, BH Han, ES Choi, S Namgung, DH Jeong, SN Jin, YJ Lee, DG Kang and HS Lee. Involvement of heme oxygenase-1 induction in anti-vascular inflammation effects of Xanthoceras sorbifolia in human umbilical vein endothelial cells. J. Tradit. Chin. Med. 2018; 38, 803-14.

[35] G Ungerer, J Cui, T Ndam, M Bekemeier, H Song, R Li, HR Siedhoff, B Yang, MK Appenteng, CM Greenlief, DK Miller, GY Sun, WR Folk and Z Gu. Harpagophytum procumbens extract 
http://wjst.wu.ac.th

ameliorates allodynia and modulates oxidative and antioxidant stress pathways in a rat model of spinal cord injury. Neuromol. Med. 2020; 22, 278-92.

[36] M Moniruzzaman, YW Chin and J Cho. HO-1 dependent antioxidant effects of ethyl acetate fraction from Physalis alkekengi fruit ameliorates scopolamine-induced cognitive impairments. Cell Stress Chaperones 2018; 23, 763-72.

[37] S Boonruang, K Prakobsri, P Pouyfung, E Srisook, A Prasopthum, P Rongnoparut and S Sarapusit. Inhibition of human cytochromes P450 2A6 and 2A13 by flavonoids, acetylenic thiophenes and sesquiterpene lactones from Pluchea indica and Vernonia cinerea. J. Enzyme Inhib. Med. Chem. 2017; 32, 1136-42.

[38] H Kobuchi, S Roy, CK Sen, HG Nguyen and L Packer. Quercetin inhibits inducible ICAM-1 expression in human endothelial cells through the JNK pathway. Am. J. Physiol. 1999; 277, C403C411.

[39] WY Huang, L Fu, CY Li, LP Xu, LX Zhang and WM Zhang. Quercetin, hyperin, and chlorogenic acid improve endothelial function by antioxidant, antiinflammatory, and ACE inhibitory effects. $J$. Food Sci. 2017; 82, 1239-46.

[40] S Wang, B Sarriá, R Mateos, L Goya and L Bravo-Clemente. TNF- $\alpha$-induced oxidative stress and endothelial dysfunction in EA.hy926 cells is prevented by mate and green coffee extracts, 5caffeoylquinic acid and its microbial metabolite, dihydrocaffeic acid. Int. J. Food Sci. Nutr. 2019; 70, 267-84. 